\title{
APPLICATION OF SELECTED TOOLS FOR IDENTIFICATION OF QUALITY DEFECTS AND THEIR COSTS IN THE CABLE MANUFACTURING PROCESS
}

\begin{abstract}
Process of control and meeting standards over the whole manufacturing process allow for providing customers with products or services with expected quality, which largely determines the competitive advantage of the enterprise. Consumers more and more often emphasize the quality of goods manufactured and the criterion of the price is often not the dominant criterion when choosing a product. This situation is observed in the automotive sector, where safety of using vehicles and human health and life are in the first place. Therefore, on the one hand, it is essential to eliminate the quality defects, and, on the other hand, one should familiarize with the causes of these defects and to prevent from them in the future. This is possible and necessary in the automotive sector, which uses the international standard of ISO/TS 16949 by employing tools and methods of quality management.

This study uses the Pareto chart and the Ishikawa diagram in order to identify significant inconsistencies and the related costs in the process of manufacturing of single-conductor automotive cables, special cables (NON-PVC) and battery cables.
\end{abstract}

Keywords: quality, quality tools, cables

\section{Introduction}

Each organization which is aimed at high quality of products and, consequently, oriented at the development in the future, has to adopt improvement initiatives in their long-term goals, thus the activities which are aimed at continuous improvement of processes and solving quality problems. The enterprises that operate in the automotive sector have a range of tools and methodologies available to be used in quality

\footnotetext{
1 Wroclaw University of Economics, Poland, Faculty of Engineering and Economics, Department of Labour and Industrial Relations, email: szymon.dziuba@ue.wroc.pl
} 
management. They were described in detail in the sector standard ISO/TS 16949 (KARASZEWSKI R 2009).

The enterprise discussed in this study manufactures cables which are electrical conductors covered with insulation. Their production involves many stages and variety of operations. Assuming that the length of various cables in personal cars is over $3 \mathrm{~km}$, the controlling, monitoring and preventive measures should be taken with respect to quality inconsistencies that might have an effect on health and life of passengers.

The quality of the final product is closely related to the manufacturing process. Therefore, it is also essential to familiarize and understand the process. In the case of the enterprise analysed in this study, manufacturing process is presented schematically in Fig. 1.

As presented in Fig. 1, one of the areas of production is division of insulation application i.e. cable extrusion, which is defined as metal forming or plastic forming using specialized equipment. In the case of the enterprise analysed in this study, extrusion concerns application of a layer of insulation on a conductor (copper cable strand) to protect from avalanche breakdown. An important role in this operation is played by the type of insulation and the method of its application on the cable strand, which is a source of quality inconsistencies at this stage of cable manufacturing (GROBICKI J., GERMATA M. 2010; JANKAJOVA E., MitOSKOVA D., LESTYÁNSZKA ŠKŮRKOVÁ K., INGALDI M. 2015). 

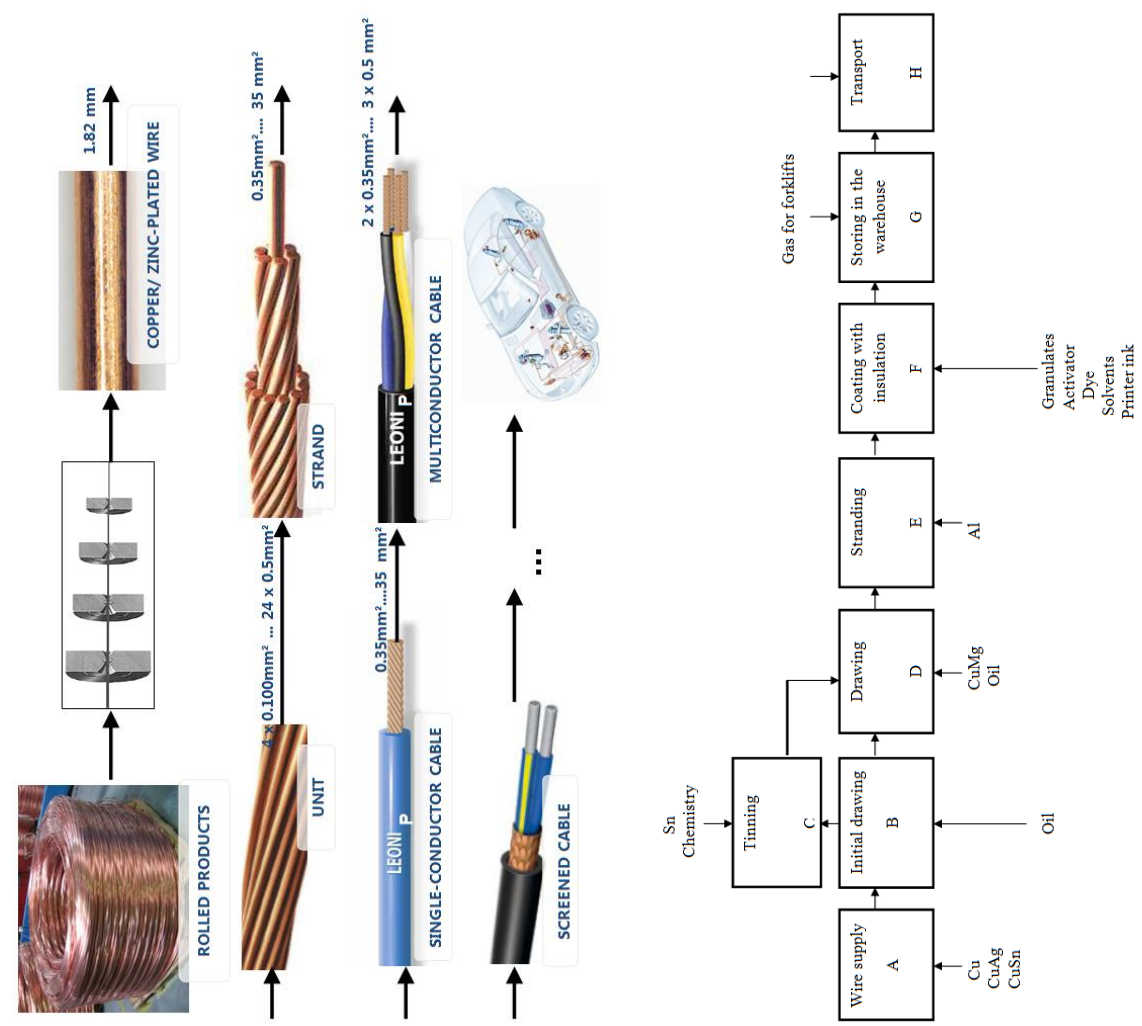

Fig. 1. The simplified diagram of cable manufacturing process.

Source: author's own elaboration based on the materials from the enterprise $X$

\section{Aim of the study and quality tools}

The aim of the study was to identify and analyse the causes of quality defects on cable extrusion line and evaluation of their significance with respect to the cost criterion.

The process of cable manufacturing is a complex process. Therefore, the focus of the study was only on internal problems that occurred in 
cable extrusion line and the examinations took 12 months starting from 1st January 2013.

The enterprise analysed in the study uses the ISO/TS 16949 standard which, apart from problems connected with efficiency and effectiveness of the quality system, also concerns the problems connected with using quality tools such as the Ishikawa diagram or Pareto chart. The effective documentation of these tools and using them in practice allows for meeting the expectations of customers.

The Pareto chart is a specific chart that is based on 20-80 principle. This means that "20\% of elements in a homogeneous set represents $80 \%$ of the value of the characteristic over the whole population, that is, $20 \%$ of causes leads to $80 \%$ of quality problems (LUCZAK J. 2008, DZIUBA S.T., PieKara A., MaŁas W., KozioŁ P. 2013).

Furthermore, the cause-and-effect Ishikawa diagram is a tool that supports the process of problem-solving through graphical presentation of causes that lead to this result. The causes are the factors that impact on specific effects. This is one of the most often used tools for solving quality problems. An important benefit of the chart is the fact that the chart is characterized by organized information, accurate analysis, clear and logical data hierarchy, diligence, emphasis on location and elimination of the causes of the defect (DZIUBA S.T., JAROSSOVÁ M.A., GOŁĘBIECKA N. 2013; LESTYÁNSZKA ŠKŮRKOVÁ K., INGALDI M., KotUS M., SABLIK J. 2014.).

\section{Classification of quality inconsistencies using the Pareto- Lorenz diagram}

The team established to identify quality inconsistencies in the division of cable extrusion presented tables with defects divided into types of cables manufactured, which is illustrated in Tables 1, 2, 3 . Furthermore, each table contains the total number of all the inconsistencies, the order of defects in terms of frequency of occurrence was identified and the percentage and cumulative percent values were 
calculated for each defect. The costs of each defect was also included in order to fully illustrate the significance of the specific inconsistencies. The Pareto charts created based on the data from Tables 1, 2, 3 (see Figs. $2,3,4$ ) have a form of a simple bar chart. Numerical data on these charts were presented in a descending order. The diagrams contain values that create a linear chart of cumulative values.

When using this methodology in practice, the focus should be on $20 \%$ of the most important inconsistencies and implement the corrective and preventive measures, which was performed in this study using the Ishikawa diagram (HAMROL A. 2008, ŁUNARSKI J. 2011).

Table 1. Classification of inconsistencies in single-conductor cables according to frequency of occurrence including the cost of the inconsistency

\begin{tabular}{|c|c|c|c|c|c|c|}
\hline 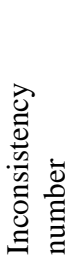 & Type of inconsistency & Cost [EUR] & 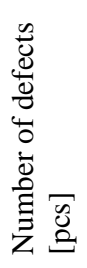 & 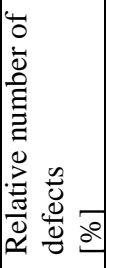 & 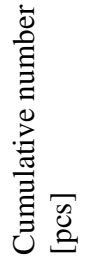 & 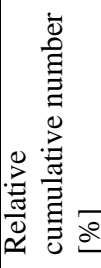 \\
\hline 1 & electrical avalanche breakdown & $64,511.69$ & 592 & 27.99 & 592 & 27.99 \\
\hline 2 & thickening & $54,828.69$ & 502 & 23.74 & 1094 & 51.73 \\
\hline 3 & major discoloration & $50,735.60$ & 409 & 19.34 & 1503 & 71.06 \\
\hline 4 & insufficient concentricity & $23,131.10$ & 141 & 6.67 & 1644 & 77.73 \\
\hline 5 & visible twist of the strand & $12,379.98$ & 125 & 5.91 & 1769 & 83.64 \\
\hline 6 & scratched insulation & $15,722.25$ & 113 & 5.34 & 1882 & 88.98 \\
\hline 7 & insufficient wall thickness & $9,285.10$ & 64 & 3.03 & 1946 & 92.01 \\
\hline 8 & rough insulation & $6,668.76$ & 60 & 2.84 & 2006 & 94.85 \\
\hline 9 & additional discoloring & $7,541.70$ & 58 & 2.74 & 2064 & 97.59 \\
\hline \multirow[t]{2}{*}{10} & insufficient amount of cable & $3,978.82$ & 51 & 2.41 & 2115 & 100.0 \\
\hline & Total & & 2115 & 100 & & \\
\hline
\end{tabular}

Source: author's own elaboration based on the materials from the enterprise studied 


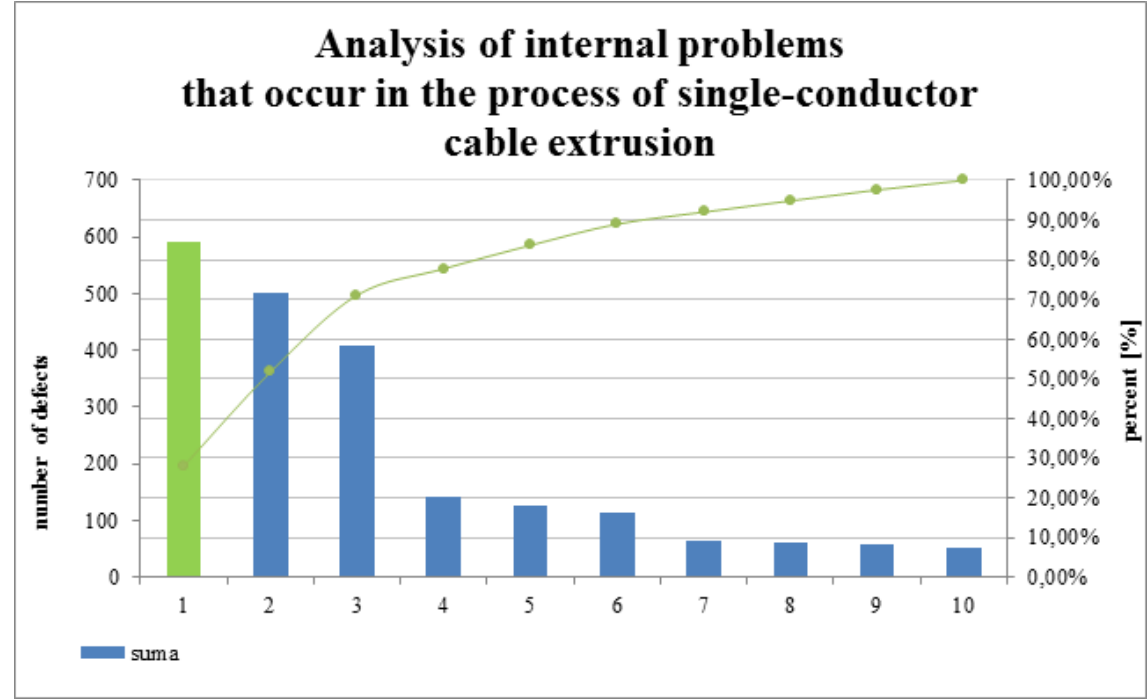

Fig. 2. The Pareto chart that presents quality defects in the process of singleconductor cable extrusion.

Source: author's own elaboration based on the materials from the enterprise studied

Analysis of the data from Table 1 and Fig. 2 leads to the conclusion that the most important problem that occurs in the process of singleconductor cable extrusion is electrical avalanche breakdown. The number of this type of defects in 2013 was 592. They generate the highest number of kilograms of cable to be scrapped. Costs of this type of defects were 64,511.69 EURO.

Table 2. Classification of inconsistencies in NonPVC cables according to frequency of occurrence including the cost of the inconsistency

\begin{tabular}{|c|c|c|c|c|c|}
\hline 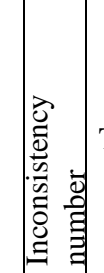 & Type of inconsistency & Cost [EUR] & 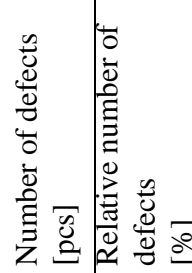 & 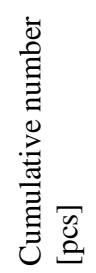 & 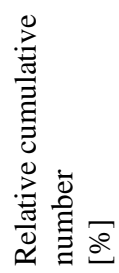 \\
\hline
\end{tabular}




\begin{tabular}{|r|l|l|r|r|r|r|}
1 & electrical avalanche breakdown & $13,916.14$ & 92 & 19.91 & 92 & 19.91 \\
\hline 2 & thickening & $10,192.09$ & 79 & 17.10 & 171 & 37.01 \\
\hline 3 & major discoloration & $9,139.20$ & 66 & 14.29 & 237 & 51.30 \\
\hline 4 & diameter differences & $9,098.30$ & 64 & 13.85 & 301 & 65.15 \\
\hline 5 & scratched insulation & $6,584.22$ & 41 & 8.87 & 342 & 74.03 \\
\hline 6 & excessive insolation removing force & $6,493.50$ & 32 & 6.93 & 374 & 80.95 \\
\hline 7 & paint smear & $5,268.80$ & 29 & 6.28 & 403 & 87.23 \\
\hline 8 & illegible print & $3,799.90$ & 28 & 6.06 & 431 & 93.29 \\
\hline 9 & blurred print & $2,619.60$ & 18 & 3.90 & 449 & 97.19 \\
\hline 10 & rough insulation & $2,967.40$ & 13 & 2.81 & 462 & 100.00 \\
& Total & & 462 & 100 & \multicolumn{2}{|c}{} \\
\cline { 2 - 5 } & & &
\end{tabular}

Source: author's own elaboration based on the materials from the enterprise studied

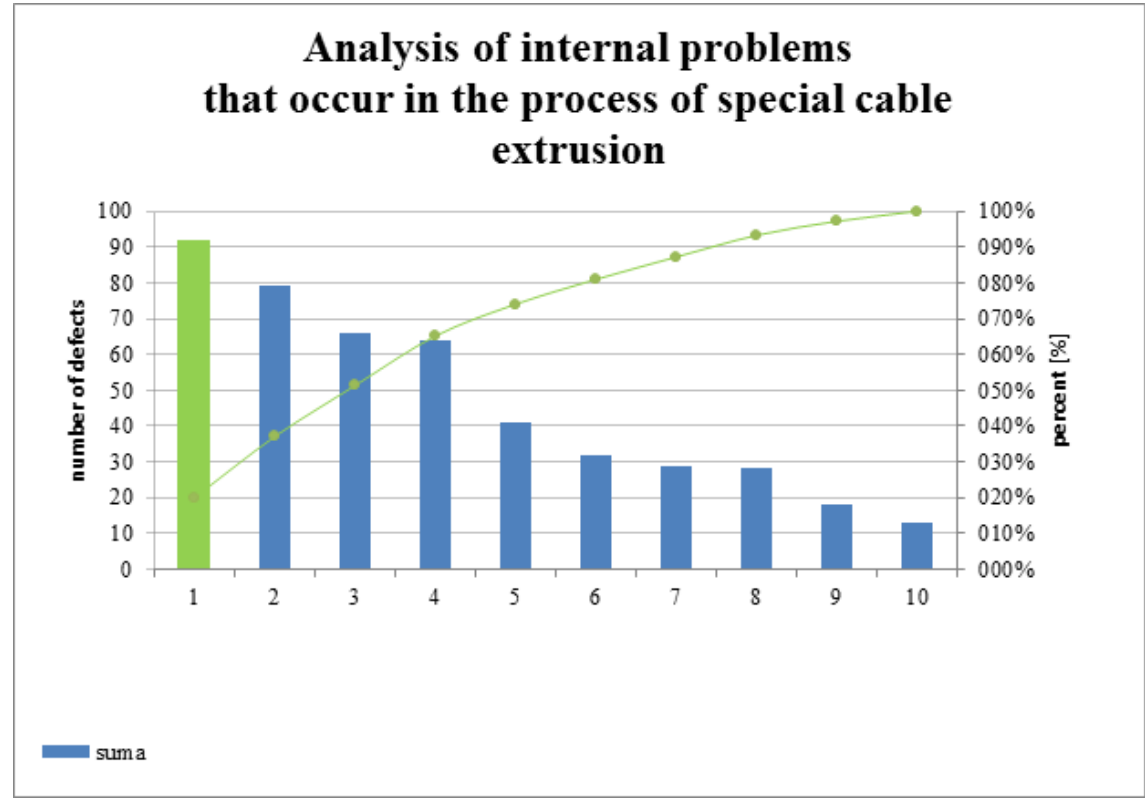

Fig. 3. The Pareto chart that presents quality defects in the process of extrusion of special (NonPVC) cables.

Source: author's own elaboration based on the materials from the enterprise studied 
Analysis of the data from Table 2 and Fig. 3 reveals that the most important problems that occurs in the process of extrusion of special cables are electrical avalanche breakdown and thickening. The number of problems that resulted from electrical avalanche breakdown was 92 and from thickening - 79. They generate the highest number of kilograms of cable to be scrapped. Total costs of this type of defects were $24,108.23$ EURO.

Table 3. Classification of inconsistencies in car battery cables according to frequency of occurrence including the cost of the inconsistency

\begin{tabular}{|c|c|c|c|c|c|c|}
\hline 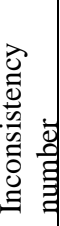 & Type of inconsistency & Cost & 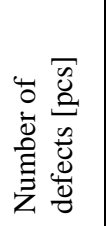 & 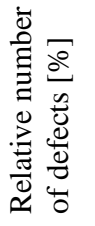 & 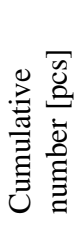 & 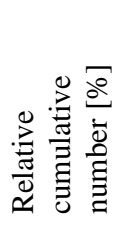 \\
\hline 1 & thickening & $40,760.33$ & 316 & 35.79 & 316 & 35.79 \\
\hline 2 & mechanical defects & $15,143.85$ & 287 & 32.50 & 603 & 68.29 \\
\hline 3 & insufficient inner diameter & $11,855.30$ & 78 & 8.83 & 681 & 77.12 \\
\hline 4 & diameter differences & $6,233.18$ & 37 & 4.19 & 718 & 81.31 \\
\hline 5 & excessive resistance & $14,648.01$ & 36 & 4.08 & 754 & 85.39 \\
\hline 6 & $\begin{array}{l}\text { insufficient outer diameter of the } \\
\text { sheath }\end{array}$ & 822.05 & 32 & 3.62 & 786 & 89.01 \\
\hline 7 & tangled cable & $6,072.07$ & 30 & 3.40 & 816 & 92.41 \\
\hline 8 & blurred print & $9,053.75$ & 30 & 3.40 & 846 & 95.81 \\
\hline 9 & insufficient external diameter & $2,116.21$ & 19 & 2.15 & 865 & 97.96 \\
\hline \multirow[t]{2}{*}{10} & $\begin{array}{l}\text { improper arrangement of colors } \\
\text { of inner conductors }\end{array}$ & $1,962.41$ & 18 & 2.04 & 883 & 100.00 \\
\hline & Total & & 883 & 100 & & \\
\hline
\end{tabular}

Source: author's own elaboration based on the materials from the enterprise studied 


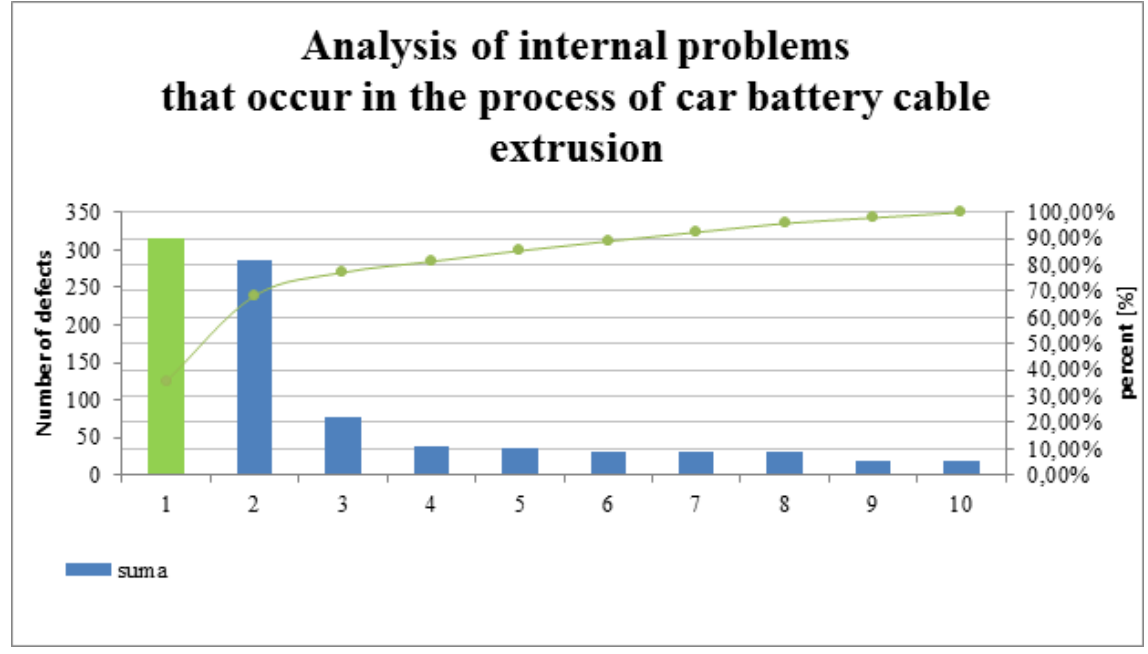

Fig. 4. The Pareto chart that presents quality defects in the process of extrusion of car battery cables.

Source: author's own elaboration based on the materials from the enterprise studied

Analysis of the data from Table 3 and Fig. 4 demonstrates that the most important problem that occurs in the process of extrusion of car battery cables is thickening. Number of problems that resulted from electrical avalanche breakdown was 316. The amount of the cable scrapped in the area of car battery cables in the case of thickening was $72,618.46 \mathrm{~kg}$ and the cost of this inconsistency was 40,760.33 EUR in 2013.

In conclusion, as demonstrated by the analyses, the main quality defects in the process of extrusion of single-conductor cables, special cables and car battery cables are:

- Electrical avalanche breakdown - the defect that consists in broken continuity of insulation. This means the places with bare face, without insulation, which is illustrated in Fig. 5. 


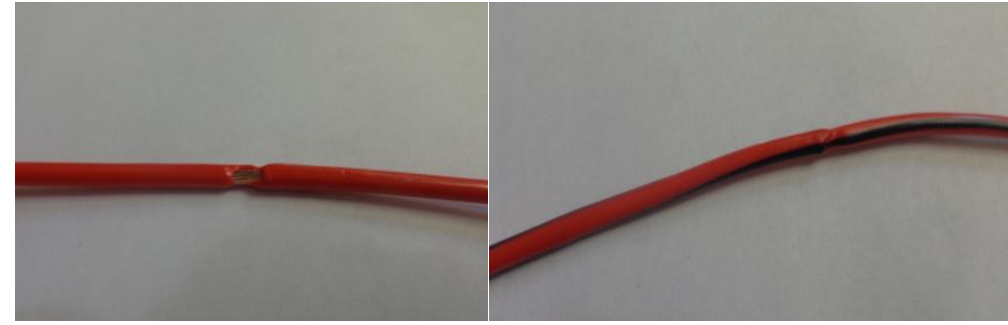

Fig. 5. Cable with damaged insulation.

Source: author's own elaboration

The defect can also occur if the thickness of the insulation wall is relatively small (Fig. 1.6).

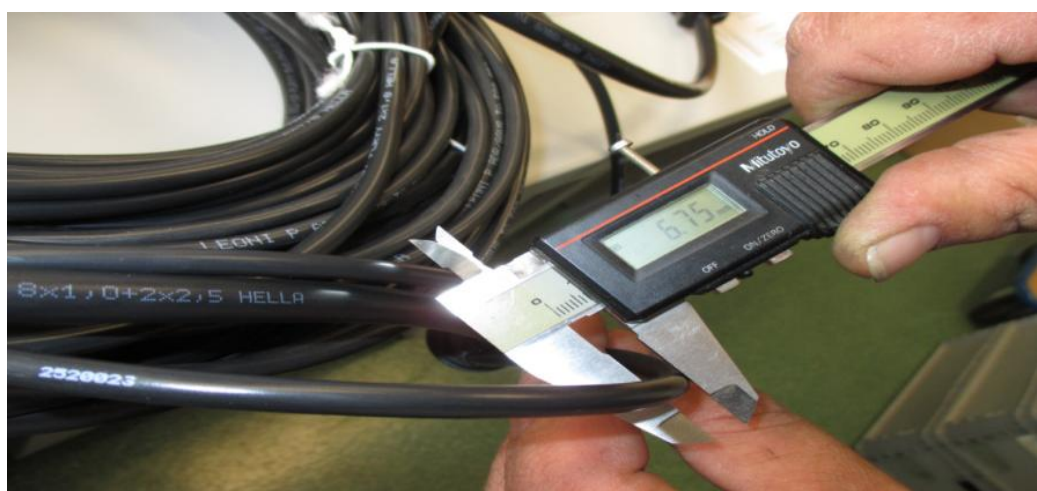

Fig. 6. Diameter outside the tolerance range.

Source: author's own elaboration

- Thickening (wick) - can be caused by burning the insulation or inclusion of foreign material (Fig. 7). 


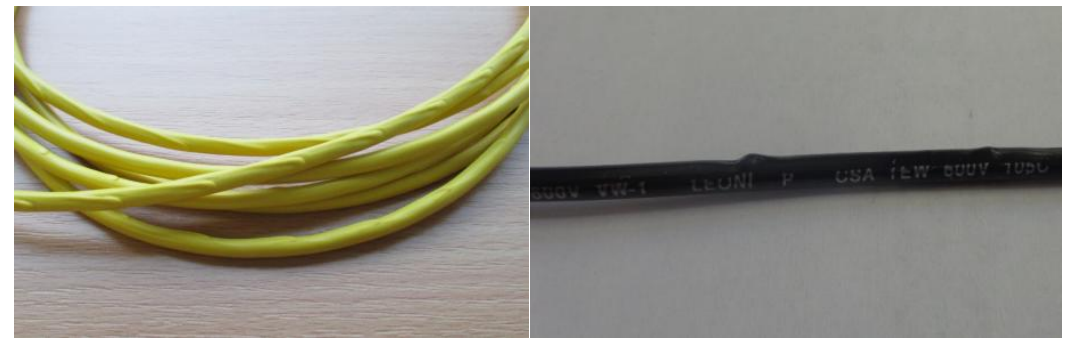

Fig. 7. Cable thickening as a quality defect.

Source: author's own elaboration

In order to identify the causes that affect occurrence of quality inconsistencies such as electrical avalanche breakdown and thickening, the team decided to carry out cause-and-effect analysis using the Ishikawa diagram.

\section{Ishikawa diagram for major quality defects}

The data and analyses of Pareto charts led to the necessity of taking all the problems that caused the highest number of product defects into consideration. In this case, two defects were most frequent: electrical avalanche breakdown and thickening. These inconsistencies were the focus of further investigations.

The team decided to use the cause-and-effect diagram which is characterized by a very transparent illustration of correlations between causes and the main problem, which offers opportunities for analysis of the phenomenon in a comprehensive, simple and logical manner.

In order to maintain a broad spectrum of analysis of the factors that potentially generate the defects of avalanche breakdown and thickening, five major areas of causes of these defects were taken into consideration. Figures 8 and 9 present the division of potential causes of individual defects. 
Zeszyty Naukowe

Quality. Production. Improvement
No. 2(3)

2015

pp. $72-87$

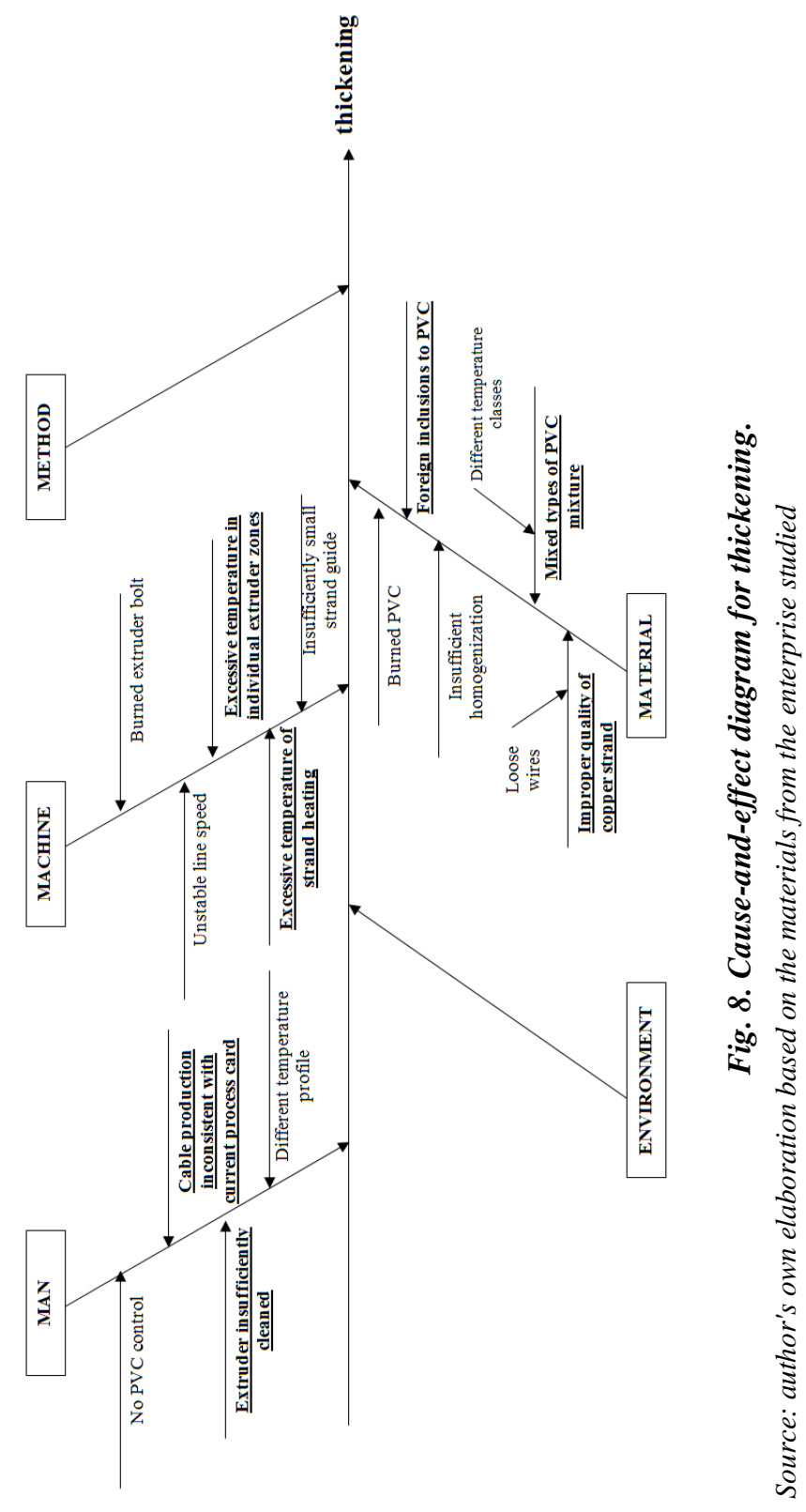


Zeszyty Naukowe

Quality. Production. Improvement
No. 2(3)

2015

pp. $72-87$

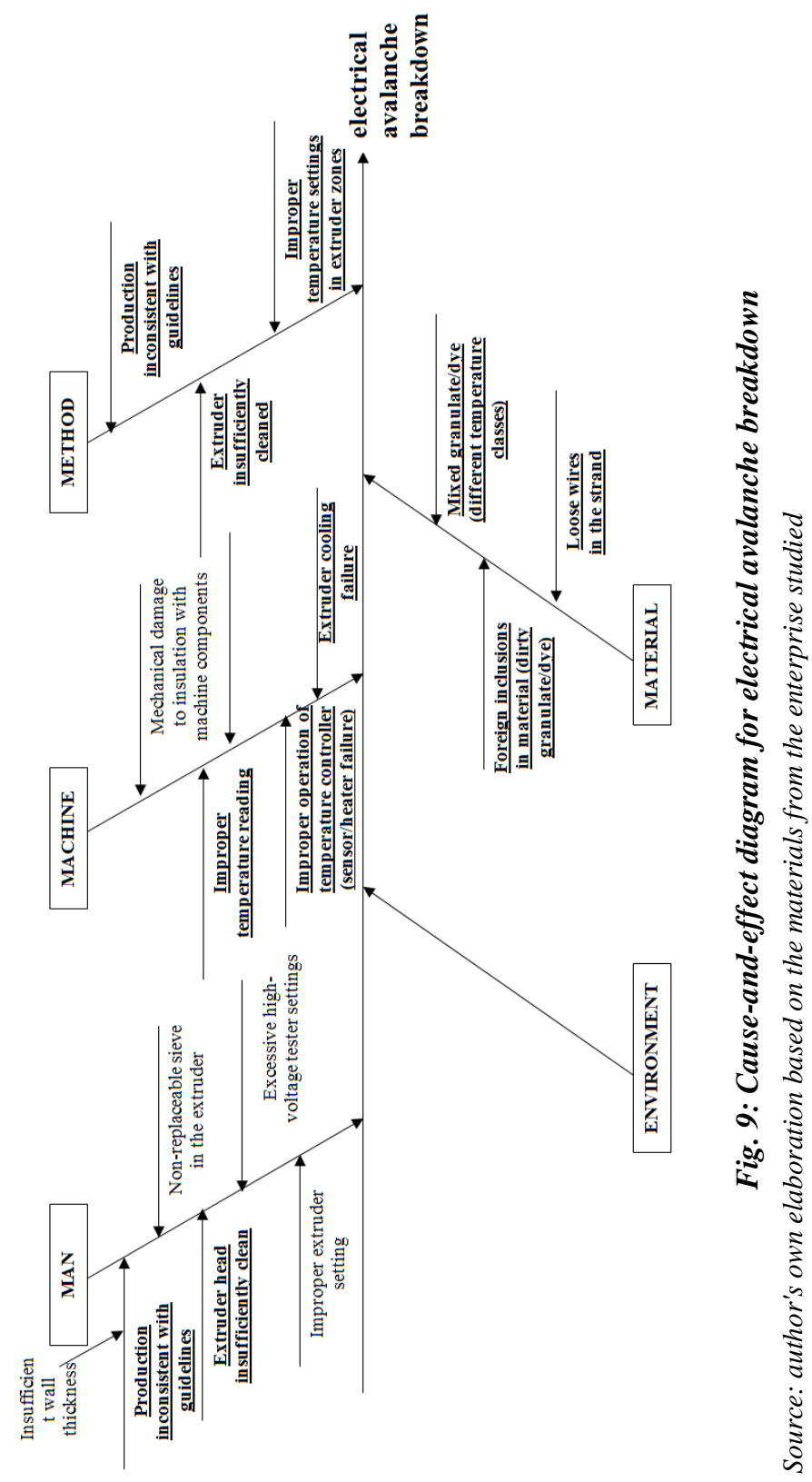


After designing the diagrams, the team separated common causes that can have an effect on occurrence of quality defects such as electrical avalanche breakdown and thickening in the production process in the cable extrusion division.

After additional analyses using the brainstorming and 5 Whys methods, Figs. 8 and 9 show (in bold and underlined) causes which should be removed first during the corrective measure and thus improving the quality of products. This translates directly into the reduction in the number of inconsistencies.

\section{Conclusions}

Every enterprise should care for the quality of products they deliver, not only because of relation with customers but also due to the costs they have to incur. Each quality defect leads to substantial financial expenditures connected with sorting the already manufactured batches to search for other defective parts or, in the worst case, stopping the production.

Before implementation of corrective and preventive measures, 12 internal defects were found on average per day in the areas connected with operation of extruder lines. These defects involved costs which had to be incurred by the enterprise due to scrapping of the defective batches of goods. In the period studied, the costs were 522.836 .58 zlotys, which, calculated per each working day, was $1,432.43$ zlotys. The cost of one defect was nearly 120 zlotys.

Since the corrective and preventive measures were implemented, including:

- modification and training for operators from the instruction manual that presents a proper material inspection and inspection of machine components that control temperature,

- thermostat control every shift,

- change of the granulate supplier, 
- inspection and verification of guidelines in production of different types of cables,

- regular (every month) training for direct manufacturing employees concerning the effect of their work on quality of the final product, the number of inconsistencies expressed in ppm units (i.e. number of defective products per million) reduced significantly.

\section{References}

1. Dziuba S.T., PieKara A., Matas W., Koziol P.: Traditional tools of quality improvement used to improve furniture production process. Monografia: S. BoRKowsKI, P. SYGUT, Control Meaning in Products and Processes Improvement, chapter 6, 2013.

2. Dziuba S.T., JarossovÁ M.A., GoŁęBIECKA N.: Applying the Ishikawa Diagram in the process of improving the production of drive half-shafts. Monografia: S. Borkowski, M. Ingaldi, Toyotarity. Evaluation and Processes'/ Products' Improement, chapter 2, 2013.

3. GROBICKI J., GERMATA M.: Przewody i kable elektroenergetyczne. Wydawnictwa Naukowo-Techniczne, Warsaw 2010.

4. Hamrol A., Zarządzanie jakościa z przykładami, Wyd. Naukowe PWN, Warsaw 2008.

5. KARASZEWSKI R., Nowoczesne koncepcje zarządzania jakościa, Dom organizatora, Toruń 2009.

6. ŁUCZAK J.: System zarządzania jakościa dostawców w branży motoryzacyjnej - ocena istotności wymagań. Wydawnictwo Akademii Ekonomicznej w Poznaniu, Poznań 2008.

7. ŁUNARSKI J.: Zintegrowane Systemy Zarzadzania. Wspomaganie zarządzania systemami standardowymi. Wydawnictwo Politechniki Rzeszowskiej, Rzeszów 2011.

8. Jankajova E., Mitoskova D., LeSTYÁnszKa ŠKŮRKOVÁ K., InGALDi M. 2015. QP- Plan kvality procesu vyroby suciastok technologiou tlakoveho liatia $=\mathrm{QP}-$ Quality plan of production process of the components by diecasting technology. [w:] Kvalita, technológie, diagnostika $\mathrm{v}$ technických 
Zeszyty Naukowe

No. 2(3)

Quality. Production. Improvement

systémoch $=$ Quality, technologies, diagnostics of technical systems. Ed. Jozef Hrubec a kolektív. Zborník vedeckých prác. SPU v Nitre.

9. LestyÁnszKa ŠKŮRKovÁ K., IngAldi M., Kotus M., SABliK J. 2014. Integration of QMS, EMS and HSMS into the enterprise's structure. [In:] Assessment of the machines conditions operation and their improvement. Ed. Stanisław Borkowski, Marek Krynke. University of Malibor, Celje, Słowenia. pp.20-29.

10. MATERIALS FROM THE ENTERPRISE STUDIED, 2013 